Nóra Séllei

\title{
Virginia Woolf and the Problem of Autobiography"
}

"Life is a strip of pavement over an abyss," wrote Virginia Woolf into her diary in October $1920 .^{1}$ In this paper I will examine how this statement functions in Woolf's late autobiographical writing, "A Sketch of the Past," left unfinished two months before her suicide. My approach to the text will be twofold: on the one hand I will make an attempt to point out how the text deconstructs itself as autobiography yet desperately insists on constructing a unified self, on the other hand I will consider it in terms of autobiographics, i.e. how the text is inscribed and defined by all those discourses (and my primary focus here will be the genre of autobiography) that create the autobiographical subject in the text.

"A Sketch of the Past" was published posthumously in the collection of autobiographical writings entitled Moments of Being, in which texts written in different periods for different audiences are collected: an oscillation between autobiography and biography (that of Vanessa) in "Reminiscences," "A Sketch of the Past," covering basically the same period of life but written more than thirty years later; and three readings ("22 Hyde Park Gate," "Old Bloomsbury" and "Am I a Snob") given, within a span of fifteen years, to a circle of close friends, the Memoir Club.

These texts are thus diverse both in their date of origin, their assumed audience or readership and their choice of autobiographical form. Yet, this is not the single reason why I have avoided so far the term autobiography, I did so because in the argument I will rely on the concept that no writing, not even the

\footnotetext{
"This essay is a revised and substantially extended version of a paper given at the Conference of English and American Studies in Timisoara, Romania in 1996 and published in the 1997 issue of B.A.S., Timisoara.

${ }^{1}$ Bell (ed)., The Diary of Virginia Woolf II. p. 72. Henceforth abbreviated as DVW
} 
so-called autobiographical can represent the verifiable absolute truth of identity; that the self cannot be truly represented in language even though autobiography came about as a genre of putting oneself into the text, of a revelation of selfknowledge, of verifiability and authentic truth-production about oneself, a genre in which the referentiality of the text is supposed to far exceed that of realist fiction. This concept of autobiography, grounded in the humanistic notion of

the self-evident existence of an autonomous, self-identical individual, is founded on the oneness of the author, narrator and subject, [and] presupposes the possibility of a whole truth which would be the property of the subject and which he could convey at will. ${ }^{2}$

This concept of autobiography, presupposing the referentiality of language and the direct availability of the author's self in the text, utilizes the "presumed factuality or historicity of autobiography." ${ }^{3}$

The homogenous identity of the self and the referentiality of language are, however, central notions problematised by poststructuralist theories on the basis that, summed up roughly, "to use signs entails that meaning is dispersed, divided and never quite one with itself. Not only meaning but ' $I$ ' too, the whole idea that I am a stable, unified entity must also be a fiction."

Inevitably, the change in the concept of the self leads to a different notion of autobiography in all its basic aspects: it erodes

the distinction between fiction and non-fiction and deconstructs the apparent relation between the self and its textual embodiment [and] autobiography is not seen as produced by a pre-existent self but as producing a provisional and contingent one. ${ }^{5}$

The same position is proposed by Paul de Man in his essay "Autobiography as De-Facement," where he argues that autobiography is

${ }^{2}$ Couser, Altered Egos. p. 23

${ }^{3}$ Ibid. p. 14

${ }^{4}$ Ibid. p. 18

${ }^{5}$ Ibid. p. 189 
not a genre or a mode but a figure of reading or understanding that occurs, to some degree, in all texts. [...] [T] he author declares himself the subject of his own understanding, but this merely makes explicit the wider claim to authorship that takes place whenever a text is stated to be by someone. ${ }^{6}$

In this way the question of fictionality/nonfictionality is not a valid distinction or a basis for any typology of texts:

[t]he interest of autobiography, then, is not that it reveals reliable selfknowledge - it does not - but that it demonstrates in a striking way the impossibility of closure and of totalisation (that is the impossibility of coming into being) of all textual sign systems made up of tropological substitutions."

Following this logic there arises the question that

whatever the writer does is in fact governed by the technical demands of self-portraiture and thus seems determined in all its aspects by the resources of their medium [...] since the mimesis here assumed to be operative is one mode of figuration among others."

Thus autobiographical writing becomes not a representation of a unifed identity but rather one version of the "technology of self." In Autobiographics Leigh Gilmore introduces a complex method of investigation, combining the approaches of deconstruction and social constructionism. She sets her aim

to describe the elements of self-representation which are not bound by a philosophical definition of the self derived from Augustine, not content with literary history of autobiography, those elements that instead mark a location in the text where self-invention, self-discovery and selfrepresentation emerge within the technologies of autobiography -

\footnotetext{
${ }^{6}$ de Man, "Autobiography as De-Facement," pp. 921-922

7 Ibid. p. 922

${ }^{8}$ Ibid. p. 920

'Nussbaum, The Autobiographical Subject. p. xiv
} 
namely those legalistic, literary, social and ecclesiastical discourses of truth and identity, through which the subject of autobiography is produced. $^{10}$

She defines autobiographics as "a description of self-representation and as a reading practice, concerned with interruptions and eruptions, with resistence and contradiction as strategies of self-representation."11

Paul de Man's and Leigh Gilmore's concepts of autobiography as a mode of representation seem to be applicable approaches to Woolf's "A Sketch of the Past," which in its very title questions the absolute control over the past and destabilises the authority of the author over the material handled: both the indefinite article and the word "sketch" suggest the incompleteness, the instability, the non-finality of the text. The title shatters the illusion of the basic assumption underlying the theory of autobiography based on the notion of the unified self and the referentiality of language. The title, rather, seems to express both a scepticism toward and the inevitability of genre constrictions, thus the text becomes a master text for autobiography, which can be conceived, in Gilmore's words, as

the collection of rules offered by and produced in language that prefigures and even determines the historical modes of expression. In other words, in choosing autobiography, a writer is both enabled and constrained by the rhetoric of the style. ${ }^{12}$

In Woolf's "A Sketch of the Past" both words: 'enabled' and 'constrained' (one could rephrase it and say enabled and disabled) function as key modes of creating the text of which the narrator seems to be self-reflexively aware. Reading the text one is confronted with a conspicuously elusive quality that results in an impact like that of the clever girl in the fairy tale who has come to the king's court and hasn't, who has brought some present to the king and hasn't, who has greeted the king and hasn't simultaneously, because she has come but on horseback, she has greeted the king but by bowing, and has brought pigeons by way of present, which the moment they are present in the king's court become absent as she releases them. This is the very effect Woolf's text produces: as

\footnotetext{
${ }^{10}$ Gilmore, Autobiographics. p. 42

${ }^{11}$ Ibid. p. 42

${ }^{12}$ Ibid. p. 70
} 
opposed to the fiction of autobiography where the illusion is sustained that the narrative ' $I$ ' can tell some verifiable truth about the subject of autobiography, in this autobiographical writing Woolf dismantles and at the same time recreates the fiction of autobiographical self-expression. The oscillation between these two modes of narratorial positions permeates the text and creates the paradoxes of assumed authenticity and admitted fictionality, assumed verifiability and admitted construction, assumed fictionality of truth-telling and admitted scepticism towards the possibility of finding and expressing a final cause. The text seems to enact the paradox of the impossibility of creating an individual life story, i.e. the "coming into being in the text," ${ }^{13}$ yet it desperately makes attempts at still re-presenting at least the "moments of being" as the "scaffolding" of the individual ${ }^{14}$ - or, "A Sketch of the Past."

The oscillation, instability, and self-deconstructing quality of the text can be located on several levels, all related to the problem of the linguistic sign, of Symbol, and of a linguistic system of signs called autobiography, a special trope of reading. Thus, this autobiographical text written intermittently in the last two years of Woolf's life, with the assumed (or, rather, imposed) intention of giving an ultimate summary and evaluation of a life from the position of finality and retrospection rather turns out to be an admission of futility, of incapacity, of inappropriateness of language and linguistic signs to create a closure that can be called self and self-expression.

Woolf's scepticism towards the elements of the symbolic system of signification she chose for herself to be a master of, i.e. the medium of language goes back to the beginning of her writing career. One could quote endlessly from her letters, diaries, essays and fictional writings. By way of illustration here is a random sample spanning over thirty years of her writer's career: "Written words of a person who is dead or still alive tend most unfortunately to drape themselves in smooth folds annulling all evidence of life" ("Reminiscences," 1908, MB 43);

Words with short wings for their heavy body of meaning, inadequate to carry them far and thus alighting awkwardly upon the very common objects that surrounded them and were to their inexperienced touch so

\footnotetext{
${ }^{13}$ de Man, "Autobiography as De-Facement." p. 922

${ }^{14}$ Schulkind (ed. \& intr), Virginia Woolf: Moments of Being, p. 82 (henceforth abbreviated as MB)
} 
massive: but who knows [...] what precipices aren't concealed in them, or what slopes of ice don't shine on the sun on the other side?

\section{(“Kew Gardens,” 1918, Complete Shorter Fiction 94)}

"Suppose one could really communicate, how exciting it would be;" 15 and "If I had the power to lift out of the past a single day as we lived about 1900, it would give a section of upper middle class Victorian life" ("A Sketch of the Past," 1940, $M B 161$, emphasis added).

In "A Sketch of the Past," however, the awareness of the unreliability and nonreferentiality of the system of linguistic signs is the most basic element of destabilising the authority of life-writing. Shari Benstock considers Moments of Being, and particularly "A Sketch of the Past" in terms of personal history and narrative, and states that "the entire project is posed on the question of self and its relation to language and storytelling strategies," 16 and draws the conclusion:

Woolf views the past not as a 'subject matter' - a content as such but rather a method, a scene-making. [...] Unable to argue logically the ontology of autobiography by means of self-consciousness, Woolf moves toward an instinctive notion that the 'sealed vessel' of selfhood is an artificial construct, that it 'cracks' and floods, allowing access to that which in conscious moments is considered wholly separate and different from self -'what is convenient to call reality'. But Woolf's notion of reality is [...] rather a linguistic space (a 'scene') that conceals - and tries to seal itself against - the gap (the 'crack') of the unconscious. [...] 'Writing the self' is therefore a process of simultaneous sealing and splitting that can only trace fissures of discontinuity. ${ }^{17}$

What I would like to further investigate is how the narrator's self-reflexive persona on the one hand consciously destabilises the authenticity of this personal narrative, while on the other hand persistently denies her own awareness of the futility of putting herself - or any other person - in a text, because in my opinion this dynamism of negation and assertion gives the key mode of the text, never

\footnotetext{
${ }^{15}$ Nicolson \& Trautman (eds)., The Letters of Virginia Woolf IV. p. 97 (Letter to Gerald Brennan, 1929, emphasis added). Henceforth abbreviated as $L V W$

${ }^{16}$ Benstock, The Private Self. p. 22

${ }^{17}$ Ibid. p. 29
} 
drawing any ultimate conclusion or taking the side of either autobiographical facement or de-facement.

In considering the narrator's position I think the narrative situation is of utmost importance, from which the question of memory, identity, re-presentating a memory/person in a text, the Woolfian notions of the 'cotton wool' and the 'moments of being,' and the disposition for scene-making are problematised. I would even argue that through this narrator, though really "unable to argue logically," Woolf was absolutely aware of the ontology of autobiography, and expounded it in a fictional treatise on autobiography, or more precisely, on the impossibility of autobiography.

The first sentences of the text imply the complexity of the autobiographical narrator's position as the site of conflicting discourses:

Two days ago - Sunday 16th April 1939 to be precise - Nessa said that if I did not start writing my memoirs I should soon be too old. I should be eighty-five and should have forgotten - witness the unhappy case of Lady Strachey. As it happens that I am sick of writing Roger's life, perhaps I will spend two or three mornings making a sketch. There are several difficulties. In the first place, the enormous number of things I can remember; in the second, the number of different ways in which memoirs can be written. As a great memoir reader, I know many different ways. But if $I$ begin to go through them and to analyse them and their merits and faults, the mornings - I cannot take more than two or three at most - will be gone. So without stopping to choose my way, in the sure and certain knowledge that it will find itself - or if not it will not matter. I begin: the first memory.

$(M B 72)$

The narrator is located in the text both in time (defining the precise date and her age) and as an authorised memoir-writer for Virginia Woolf the woman (the sister of Vanessa Bell) and the writer (the writer of Roger Fry's biography) who is still fully capacitated to recall memories (in opposition to Lady Strachey the problem is the great number of memories), with a personal knowledge of the conventions of writing a memoir and with the certainty that whatever she writes will sort out itself into a form, even if not into a conventional one. Yet, parallel with locating the narrator into this stable position of authority, all these elements are undermined and opened up in the same sentences. 
The temporal location of the narrator's story-telling is sustained all through the text: the first date is 16th April 1939, the last 15th November 1940, but it is also known that Woolf stopped writing it in January $1941,{ }^{18}$ two months before her suicide. These dates function significantly in the text: they are defined not only chronologically but also historically and psychologically: what it means to live under the threat of old age, of a possibly approaching bout of madness, under the threat of the German invasion (their house in London was ruined, a German helicopter passed their garden in Rodmell, and with her husband, who was a Jew, they decided to take poison should the Germans invade Britain - $M B$ 111). For the memoir writer all these three threats lead to the same: the loss of memory, that is the loss of the idea of putting oneself into the text. The narrative situation is thus the classic case of the memoir: to remember one's self in the face of death, in the face of annihilation, and to recapture the essence of identity in the very last possible moments. One would suppose that this is the moment, the ultimate moment of being, when in spite of all the awareness of fragmentation and the inauthenticity of language a life-story is produced which, even though a "representation of [one's] imagined relation to reality, mediated by narrator and reader,"19 appears in the form of a relatively continuous and organic narrative, with the gaps successfully hidden. In the case of "A Sketch of the Past," however, the text does not even presume self-knowledge but from the first moment on problematises itself as an agent of representation and creates itself as fiction.

Old age, as a key element of the first paragraph, has ambiguous interpretations: it is not only the repository of the specular moment of autobiography, i.e. of remembering, but also that of forgetting memories (Lady Strachey's case). At this point forgetfulness is dismissed in a matter-of-fact way by stating that the problem now is rather the abundance of memories, but the comment obviously raises the question of selection: of inclusion in and omission from the text, with its concomitant issue of "true" representation. Later on, further theoretical questions are raised, most probably informed by Freud, whose works Woolf read right before writing "A Sketch of the Past" - they even met personally -, and to whom there is a reference in the text pointing out that his theory helped in analysing the love and hate relationship of the daughter to the father, Sir Leslie Stephen $(M B 120)$. One can justifiably suppose that one of the major discourses shaping "A Sketch of the Past" is Freudian psychoanalysis, a powerful fiction of

\footnotetext{
${ }^{18}$ deSalvo, Virginia Woolf and the Impact of Childhood Sexual Abuse. p. 132

${ }^{19}$ Nussbaum, The Autobiographical Subject. p. xiii, emphasis added
} 
the 20th century in other aspects as well: "the things one does not remember are as important; perhaps they are more important" ( $M B$ 78). How can, then, the reader ultimately presume the narrator as the authority of a life-story? At its best, the author may function as the authority of the story, which is the textual and symbolic substitution of life in a fiction of autobiography.

The unremembered (repressed? forgotten? unuttered because unutterable?) memories are attributed great significance in the context as they are contrasted with and posited as perhaps even more important than the first memories, the validity of which, in turn, undergoes a series of devaluations. The last phrase of the first paragraph is: "the first memory" (MB 73). Together with the narrative situation, in the face of death, summing up the essence of one's life, they form the most traditional framework possible for an autobiography: the first and the last, the beginning and the end, the departure and the destination, the origin and the goal, thus implying the perfect structure for the teleology of a personal narrative, which Paul de Man terms "the need to move from cognition to resolution." ${ }^{20}$ The authenticity of the first memory, however, is undermined in several ways, not only by stating that the unremembered things might be more important. The narrator self-confidently sets out to describe the first memory, thus to authenticate the life-story with a proper beginning:

This was of red and purple flowers on a black ground - my mother's dress; and she was sitting either on a train or in an omnibus, and I was on her lap. Perhaps we were going to St Ives; more probably, for from the light it must have been evening, we were coming back to London. But it is more convenient artistically to suppose that we were going to $\mathrm{St}$ Ives, for that will lead to my other memory, which also seems to be my first memory, and in fact it is the most important of all my memories.

(MB 72-3; emphasis added)

At the moment the life-story is authenticated by rendering a beginning to it, it is destabilised by fictionalising and dispersing it into other origins: the memory of St Ives, lying in the nursery and listening to the waves as they break on the shore. Is there $a$ beginning, then? Or are there different beginnings? Which is the real one? Is there any real one? This other first memory is introduced by a typically devious sentence: "If life has a base that it stands upon, [...] if it is a bowl

${ }^{20}$ de Man, “Autobiography as De-Facement.” p. 922 
that one fills and fills - then my bowl without a doubt stands upon this memory" (MB 73). The sentence can be read in at least two ways: on the one hand as a pretence for tentativeness the underlying assumption of which is yet that of affirmation: yes, this is the base of her life. On the other hand it can be interpreted as the questioning whether one can ascertain at all that life has a base, i.e. whether what is constituted as the beginning, the origin, the point of departure has any verifiable validity of that kind.

Typically, the two first memories, complemented by a third one, and all the three described in details, can be defined as memories recalled, reconstructed from the child's dyadic unity with the mother, the primordial unity of being, from the pre-Oedipal and pre-linguistic phase: the memory of sitting in the mother's lap, really close to her dress; then in St Ives lying in the nursery and listening to the waves "feeling the purest ecstasy I cannot describe" (MB 73); and finally

colour-and-sound memories [...]; it was highly sensual. [...] It still makes me warm; as if everything were ripe; humming, sunny, so many smells at once; and all making a whole that even now makes me stop, [...] and all seemed to press voluptuously against some membrane; not to burst it; but to hum round one such a complete rapture of pleasure that $i$ stopped, smelt; looked.

$(M B 75)$

These images suggest the unity and the totality of being, not in its separation and differentiation but in its primordial wholeness and oneness: on the verge of selfconsciousness, on the verge of differentiation and ego-formation, on the verge of entering the Symbolic and of falling into Oedipal sexuality (see the images of high sensuality pressing but not bursting the membrane and giving pleasure). This is the moment of Kristeva's jouissance, the moment of bodily contact when the body is not split into senses but is enwrapped in the totality of sensual pleasure, without any conciousness of the self ("half awake, half asleep"). Paradoxically, the selfconscious narrator attempts to evoke these memories, to reconstitute them in the Symbolic, in linguistic differentiation, and the failure is appropriately admitted at the end of both: "such ecstasy I cannot describe" ( $M B$ 74); "But again I cannot describe that rapture" (MB 75).

To give the logic - or "illogic" - of the text one more twist (or, to reveal one more gap), the relatively long description of these memories, concluding in 
the impossibility of verbalising the feeling, are, though not directly, preceded by the narrator's pondering:

I could spend hours trying to write [the purest ecstasy I can conceive] as it should be written. [...] But I should fail (unless I had some wonderful luck); I dare say I should only succeed in having the luck if I had begun by describing Virginia herself.

$(M B 73)$

Of this reflection three elements deserve attention. First of all the auxiliary 'should': "as it should be written." What can it refer to? What authority does it acclaim? The authority of the tradition of autobiography? The narrator's own authority? The text's authority? The memory's authority that wants to be put in the text? Perhaps all these, perhaps none of these. So, instead of solving the problem (or even clarifying it), the narrator rather seems to avoid it by forecasting failure only to give herself yet another chance and self-confidence: to describe Virginia - yet another base on which the long descriptions of the first memories can be "solidly" based.

Further complication and destabilisation ensue when this solid base quite expectedly - becomes unstable. As opposed to what seems to have been one of the most self-evident tasks of any novelist and fiction writer, i.e. the verbal characterisation of human beings, it turns out that it is not only these primordial memories that cannot be put in the text. The self-reflexive narrator raises the following question:

Here I come to one of the memoir writer's difficulties - one of the reasons why, though I read so many, many are failures. They leave out the person to whom these things happened. So they say: 'This is what happened'; but they do not say what the person was like to whom it happened.

(MB 73).

This is the question of coming into being in the text, the question of the possibility of verbal and symbolic representation, which Paul de Man phrases as the metaphorical substitution of the subject in a situation instead of the subject 
being in the text. ${ }^{21}$ Facing the abyss of nonreferentiality of language, the narrator relapses into the most commonplace and most hackneyed way possible to answer the question 'Who was I then?' Adeline Virginia Stephen, the
second daughter of Leslie and Julia Prinsep Stephen, born on 25 th Janu-
ary 1882 , descended from a great many people, some famous, others ob-
scure; born into a large connection, born not of rich parents, but of well-
to-do parents, born into a very communicative, literate, letter writing,
visiting, articulate late nineteenth century world.

$(M B 73)$

How can this, in Woolf's case most unnatural and atypical self-definition be interpreted? Obviously, on the one hand as a mockery of what Woolf ridicules in her essays "Modern Fiction" and "Mr Bennett and Mrs Brown," i.e. what she calls "materialist Edwardians," who only consider the external material world but never look at the human being, in this case called Virginia Stephen. The passage, however, probes deeper. It can also be read as absolute despair over the impossibility of representation and the admission that one symbolic substitution is as good (or, rather, as bad) as another, thus annihilating all her self-confidence in the superiority of the kind of writing she advocated. On yet another level, it can be read as the ultimate result of self-persuasion that, in spite of all the doubts, writing, i.e. an attempt at self-representation must go on and in this effort such conveniences are at disposal as the traditional form of autobiography, in which one can feel comfortable because the homeliness of the technology of the genre offers a framework for the technology of self, for the textual reconstruction of the self - whatever that is.

The doubts, quite obviously, do not spare the identity of the self either. The previous question "Who was I then?" in itself deposes the authority of the narrator over her own subject by declaring herself not a master of her own understanding. This split between the narrator and the subject is further multiplied and dispersed in time and space and in terms of social discourse. The narrator writes,

2nd May... I write the date, because I think I have discovered a possible form for these notes. That is, to make them include the present - at least enough of the present to serve as platform to stand upon. It would be in-

\footnotetext{
${ }^{21}$ Ibid. p. 921
} 
teresting to make the two people, I now, I then, come out in contrast. And further, this past is so much affected by the present moment. What I write today I should not write in a years's time.

( $M B$ 84, emphasis added)

Later she adds:

Consider what immense forces society brings to play upon each of us, how that society changes from decade to decade; and also from class to class; well, if we cannot analyse the invisible presences we know very little of the subject of the memoir.

$(M B$ 90)

The identity of self, thus the narrator and the subject of autobiography, i.e. the authority of autobiography as the repository of self-knowledge, at this point are problematised in directions different from the question of textual selfrepresentetion: both the narrator and the subject are exposed to a matrix of infinite variables in which the innumerable versions of both selves (i.e. that of the narrator and the autobiographical subject) multiply each other thus capable of creating an endless number of texts, none of which can be the authorised version, the sacred narrative of the personal history. After deposing the base of the autobiographical subject's life-story ("If life has a base..."), at this point the narrator is destabilised under the pretence of discovering a solid base: the present, more exactly the date, which apparently looks solid, but actually keeps shifting ("What I write today I should not write in a year's time"), and in its interplay with the continually shifting 'identity' of the subject it engenders a process in which the endless number of significations only "demonstrate the impossibility of closure and of totalization of all textual systems." 22 This is the basic reason why, I think, Woolf is absent from her memoir, not, as Shari Benstock argues,

because of the circumstances of her upbringing Woolf does not know 'how far [she] differ[s] from other people.' [As] it is precisely this difference, this individuality on which the traditional memoir premises itself, $^{23}$

${ }^{22}$ Ibid. p. 922

${ }^{23}$ Benstock, The Private Self. pp. 24-25 
though inevitably she is absent from it.

In spite of the tragic - or rather tragicomic - awareness of the impossibility of closure, the narrator carries on with her desperate attempts to put herself into the text and find a fitting formula. Deviously and apologetically, she complains that

I have no energy at the moment to spend upon the horrid labour that it needs to make an orderly and expressed work of art; where one thing follows another and all are swept into a whole. Perhaps, one day, relieved from making works of art, I will try to compose this.

$(M B 84)$

The question is if "A Sketch of the Past" is really an uncomposed piece of writing without any structural unity at all. The editor of Moments of Being characterises the text as "a consciouosness which follows its own particular byways rather than a preordained route," ${ }^{24}$ a statement that needs a slight revision. First, when considering the writing technique the reader must be aware that the general method of Woolf's novels from Jacob's Room on was what she laid down in her essay "Modern Fiction":

Let us record the atoms as they fall upon the mind in the order in which they fall, let us trace the pattern, however disconnected and incoherent in appearance, which each sight or incident scores upon the consciousness. [...] Any method is right, every method is right, that express what we wish to express. ${ }^{25}$

In this sense "A Sketch of the Past" is not a unique piece of writing, quite on the contrary, it perfectly fits into Woolf's fictional oeuvre. One can, therefore, wonder how much the text lacks what Woolf considers "wholeness", particularly because the other 'truth-producing' discourse most probably informing the text, i.e. Freudian psychoanalysis must have reinforced Woolf's deeply rooted conviction of her mode of representing characters in fiction: by entering the mind, quite similarly to the method required by Freud's technique of free associations.

\footnotetext{
${ }^{24}$ Schulkind, Virginia Woolf: Moments of Being. p. 20

${ }^{25}$ Lodge, Twentieth Century Literary Criticism. pp. 89-90
} 
In spite of the apparently random ramblings of the memoir, there is still a stable structure governing the text, a structure quite traditional, usual, something offered by the genre of autobiography, enabling the narrator to adopt a literary discourse with its concomitant positive effects: by accepting the structure of the memoir, $a$ narrative becomes available, a fictional space in which an identity can be constructed, and the effect of $a$ unified self can be produced. The framework of the fiction of autobiography consists, on the one hand, in the careful recurring dating of the moment of writing, on the other hand, of an absolutely chronological succession of the stages of childhood, represented by central characters dominating each stage. The key characters thus are Julia Jackson Stephen, the mother, then the first surrogate mother, Stella, preceding the father's figure, who seems to dominate the family's life after Stella's death, but parallel with this seemingly central position, the absolute centre as such is dispersed into a diversity of relationships: Vanessa, Thoby, and George Duckworth alternately gain a special role in a system of delicate interdependences. Yet, despite the simultaneity of dispersed focuses, a basic chronology of objective time is observed.

Autobiography as a mode of storytelling is also characterised by the convention that primarily the narrator's and/or the autobiographical subject's ideas and thoughts are presented and interpreted, the other characters are rather presented from the outside, defined from an external perspective. This element of autobiographics produces a narrative in which the exclusive authority of truthtelling is the narrator, relating all incidents, situations and characters to herself, even though some scepticism pervades the narrator's self-reflexive remarks on the re-presentation of the others: real representation is impossible. This doubt recurs concerning all the characters. Sometimes this happens in an indirect way, e.g. after discounting the category of 'type' as caricature both the father's and Jack Hills's figures are defined as 'types': the father is a type "like a steel engraving, without colour or warmth or body; but with an infinity of precise clear lines" (MB 120), whereas Jack Hills "stands in [her] mind's picture gallery for a type - and a desirable type; the English country gentleman type. I might call it, by way of running a line round it" (MB 112). In some other instances, most conspicuously in the mother's case, the inaccessibility of the core of the character is articulated by the narrator: "But can I get any closer to her without drawing upon all those descriptions and anecdotes which after she was dead imposed themselves upon my view of her?" (MB 92); "[b]ut if I turn to my mother, how difficult it is to single her out as she really was; to imagine what she was thinking, to put a single 
sentence into her mouth! I dream: I make up pictures of a summer's afternoon" (MB 97).

The more or less openly admitted incapacity of representing the family members has a devastating effect on representing the subject of autobiography as well because they should all function as metonymic tropes for the autobiographical subject: to 'name' and identify her by their presence in the text, by the image of the diversity of their relationships. The insufficiency of verbal representation is expressed in her recurrently expressed desire for an image, a picture, a vision, a painting ("Yet, if one could give a sense of my mother's personality one would have to be an artist" [ $M B$ 95].). True, representation in painting is another kind of substitution, another type of symbolic representation with its special system of codes, yet the spatial images of painting seem to be closer to the images of the mind: as opposed to the analytic and temporal representation of the linguistic system, they are synthetic and spatial, which always had an appeal to Woolf from the beginning of her writing career. Coming back from Italy she envied the interrelatedness of the parts in Perugino's painting, ${ }^{26}$ and in To the Lighthouse it is Lily Briscoe, the painter finishing her painting in a way that can be read as a balance between the Symbolic and the semiotic, the paternal and the maternal, the Oedipal and the pre-Oedipal, ${ }^{27}$ and it is Lily Briscoe who seems to represent the ideal artist figure.

Knowing this preference for images and pictures it is almost natural that the essential moments of life are recorded in scenes, which are the closest to an image: as opposed to dependence on temporality, they rather constitute a suspension, a frozen moment, an eternalised momentariness. This is how in the autobiography all the moments of being are represented: in scenes, in symbols. "I could sum up [Stella's death] in one scene [...] Still the leafless tree is to me an emblem, the symbol of those summer months" (MB 154), one of the tragic moments of being in her life. The phrase 'moments of being' is very often referred to, quoted and taken for granted as the symbol for the essential moments of life, for the intensive moments of subjective time, for moments of great duration, and this is what the definition suggests: "These moments of mine were scaffolding in the background, were the invisible and silent part of my life as a child" (MB 82), in sharp contrast with "this cotton wool, this non-being" (MB 79), which is disproportionately more extensive in quantity.

\footnotetext{
${ }^{26}$ Bell, Virginia Woolf: A Biography. I. p. 138

${ }^{27}$ Minow-Pinkney, Virginia Woolf and the Problem of the Subject. p. 115
} 
Yet, the moment the text defines these moments of being with an almost religious and metaphysical enthusiasm: "behind the cotton wool is a hidden pattern; that we - I mean all human beings - are connected with this, that the whole world is a work of art; that we are parts of a work of art" (MB 81), the moment it is eulogised, the typical oscillation and self-contradiction of the text begins:

we are the words; we are the music. [...] If I were painting myself I should have to find some - rod, I shall say - something that would stand for the conception. It proves that one's life is not confined to one's body and what one says and does; one is living all the time in relation to some background rods or conceptions. Mine is that there is a pattern hid behind the cotton wool.

(MB 81-2 emphasis added)

The latter voice is that of the sceptical narrator, contradicting and resisting the previous one, and discounting the authority of truth-telling: the moments of being themselves are consciously conceived by the narrator as the integral part of a conception, i.e. the symbolic substitutions for the inexpressible, the unrepresentable; supposedly good representations, though, they constitue the rod, just like the line drawn in the middle of Lily Briscoe's painting, representing Mr Ramsay, his lighthouse, phallic authority, the Oedipal and the symbolic representation in language.

A further investigation in the nature of how these moments are presented in scenes seems to irrecoverably shatter the reader's belief in the control of the narrator over the text. Scene-making has its convincing definition and rationale given by the narrator:

I find that scene making is my natural way of marking the past. A scene always comes to the top; arranged; representative. This confirms me in my instinctive notion - it is irrational; it will not stand argument - that we are sealed vessels afloat upon what is convenient to call reality; at some moments, without a reason, without an effort the sealing matter cracks; in floods reality; that is a scene - for they would not survive entire so many ruinous years unless they were made up of something permanent; that is a proof of their 'reality.' 
The notions, however, that characterise these 'scenes', or linguistic spaces ("comes to the top, arranged, representative"), are typical of the conscious, the artistic, the symbolic, the constructed and self-contained whole. The narrator is well aware of the falsity of this neat pattern, of the shallowness of the image: "Scenes, I note, seldom illustrate my relation with Vanessa; it has been too deep for 'scenes'." (MB 156).

Yet, the whole text is constructed upon a series of scenes representing the moments of being which stand for the metaphorical substitutions for the images of the persons who should, in turn, function as metonymical tropes for the identification of the image of the autobiographical subject, although in all these shifts and substitutions the closure becomes more and more impossible, the gap absolutely unbridgeable. This is the process Paul de Man calls autobiography as de-facement:

one's name is made as intelligible and memorable as a face. Our topic deals with the giving and taking away of faces, with face and deface, figura, figuration and disfiguration. [...Thus] autobiography veils a defacement of the mind of which it is itself the cause. ${ }^{28}$

Yet, the sceptical narrator, aware of the tragicomic effect of her effort, just like Sysiphos, does not give up her effort of putting herself in the text. More exactly, she does give it up: the autobiography is left unfinished...

The ultimate question remains: why is the narrator of "A Sketch of the Past" oscillating between authorising her own text and parallel with that undermining that position; why does she take all her efforts to position her story within a discourse of truth and identity while at the same time she creates not only gaps but abysses in the text? Louise deSalvo argues that Woolf stopped writing this autobiography because on the one hand her reading Freud may have put pressure on her to reinterpret what she had already written, which she was unwilling to do; on the other hand Woolf seems to have abandoned writing when she uncovered the so far unuttered element of Gerald Duckworth's sexual abuse when she was six or seven: the pain of breaking her hymen. ${ }^{29}$

The memory comes to the surface not haphazardly: "A Sketch of the Past" is informed by a series of efforts working against Victorian taboos such as

\footnotetext{
${ }^{28}$ de Man, “Autobiography as De-Facement." pp. 926, 930

${ }^{29}$ deSalvo, Virginia Woolf and the Impact of Childhood Sexual Abuse. pp. 131-132
} 
the taboo of death, birth, sexuality, the sanctity of childhood innocence and of the family. In this context the traumatic memories of her sexual abuse by both her stepbrothers provide a framework for the narrator's insistance on telling the truth, which is held back by

the rules of the game of Victorian society. [...] We still play the game. It is useful. It also has its beauty, for it is founded upon restraint, sympathy, unselfishness. [...] But the Victorian manner is perhaps - I am not sure - a disadvantage at writing. [...] On the other hand, the surface manner allows one, as I have found, to slip in things that would be inaudible if one marched up straight and spoke out loud.

$(M B$ 164)

What is so difficult to come out with? What is it that Woolf rather finds better to slip in? In Moments of Being right after the first memory comes the memory of the first abuse. After making up a series of reasons for her looking glass shame, this traumatic experience is revealed, even if not in its entirety, at the beginning. When the text ceases, on the other hand, the narrator is struggling to make the story of a supposedly seven or nine year long sexual abuse by the other stepbrother, George, audible: the period between 1895/7-1904. It follows the mother's death, when "a finger seemed laid on one's lips. [...] A finger was laid on our lips" (MB 104, emphasis added) repeats the narrator in a more affirmative and personal way on the same page. The taboo of incest, of sexual abuse even in 1940 prevents her from "telling the truth about my experiences as a body. [This is a problem] I do not think I solved. I doubt that any woman has solved it yet," writes Woolf in her essay "Professions for Women". ${ }^{30}$ The final twenty-four pages of Moments of Being are taken up by the effort of articulating and at the same time avoiding the most traumatic experience of those years.

Why do I shirk the task of wafting [Thoby] from the boat to my bedsitting room at Hyde Park Gate? It is because I want to go on thinking about St Ives. [...] I do not want to go into my room at Hyde Park gate. I shrink from the years 1897-1904, the seven unhappy years. [...] I am not thinking of mother and Stella; I am thinking of the damage their

\footnotetext{
${ }^{30}$ Gilbert \& Gubar (eds)., The Norton Anthology of Literature by Women. p. 1387
} 
deaths inflicted. I will describe it more carefully later, I will illustrate with a scene or two.

(MB 149-50)

This suspense could be interpreted as a natural remark of a narrator making up the story. But what makes it conspicuous and unique is that it has only one more parallel in the text: nowhere else can we read any other remark creating a suspense but twenty pages later, when after the description of George the narrator starts interpreting the character. In him "[s]ome crude wish to dominate there was; some jealousy, of Jack no doubt; some desire to carry away the prize; and, as became obvious later, some sexual urge" (MB 168). The structure of the argument follows the same pattern as the one attached to the looking-glass shame: a natural feeling of guilt because of being a tomboy; the inherited streak of the Puritan; some ancestral dread; being ashamed or afraid of her body; and then "another memory, also of the hall may help to explain this," and then comes the memory when Gerald Duckworth lifted her on a slab and explored her body (MB 77), as if it were the most negligible reason, only a 'may', attached to the series of reasons, just like George's "sexual urge", which became obviously traumatic in Woolf's life. But the text of "A Sketch of the Past" never releases the suspense the remark ("as became obvious later") creates: the text ceases and only silence speaks.

One can interpret this giving up in several ways: on the one hand as Louise deSalvo does, based on Woolf's diaries, that introspection became too painful and under the direct threat of the German invasion Woolf felt the coming of a new bout of depression. On the other hand, it can be interpreted as the victory of Victorian self-restraint, taboo, the finger on the lips. The silence, however, can also be interpreted as the ultimate conclusion of a narrator who from the very beginning of the text is sceptical about her authority, about the possibility of any textual representation, about the closure between the referent and the sign, about the process of signification. This narrator, who still maintained the game of authorising her text, gives up writing at the moment when a new system of signs, with referents supposedly never voiced before, i.e. a new language is needed to tell the truth about herself as a body. At this moment all pretence for textual representation fails: the strip of pavement that writing represents becomes insufficient and shaky, providing only a temporary, false and artificial bridge over the abyss of life. 


\section{BIBLIOGRAPHY}

Bell, Anne Olivier (ed.): The Diary of Virginia Woolf. I-V. London: Hogarth Press, 1975-1980.

Bell, Quentin: Virginia Woolf: A Biography. I-II. London: Hogarth Press, 1972.

Benstock, Shari: The Private Self. Theory and Practice of Women's Autobiographical Writings. London: Routledge, 1988.

Couser, G. Thomas: Altered Egos. Authority in American Autobiography. Oxford: OUP, 1989.

de Man, Paul: "Autobiography as De-Facement." Modern Language Notes. 94 (1979) $919-30$

deSalvo, Louise: Virginia Woolf and the Impact of Childhood Sexual Abuse on Her Life and Work. New York: Ballantine Books, 1989.

Dick, Susan (ed.): The Complete Shorter Fiction. London: Triad Grafton Books, 1989.

Gilbert, Sandra M. \& Susan Gubar (eds.): The Norton Anthology of Literature by Women. The Tradition in English. New York \& London: W. W. Norton \& Co., 1985.

Gilmore, Leigh: Autobiographics. A Feminist Theory of Women's Self-Representation. Ithaca \& London: Cornell Univ. Press, 1994.

Lodge, David: Twentieth Century Literary Criticism. A Reader. London: Longman, 1972.

Minow-Pinkney, Makiko: Virginia Woolf and the Problem of the Subject. Brighton, Sussex: Harvester Press, 1987.

Nicolson, Nigel \& Joanne Trautman (eds.): The Letters of Virginia Woolf. I-VI. London: Hogarth Press, 1975-1980.

Nussbaum, Felicity A.: The Autobiographical Subject. Gender and Ideology in Eighteenth-Century England. Baltimore \& London: The Johns Hopkins Univ. Pr., 1989.

Schulkind, Jeanne (ed. \& intr.): Virginia Woolf: Moments of Being. London: Grafton Books, 1976. 